\title{
The relationship between cork oak growth patterns and soil, slope and drainage in a cork oak woodland in Southern Portugal
}

\author{
Augusta Costa *, Manuel Madeira, Ângelo Carvalho Oliveira \\ Instituto Superior de Agronomia, (Universidade Técnica de Lisboa), Tapada da Ajuda 1349-017 Lisboa, Portugal \\ Received 3 July 2007; received in revised form 9 November 2007; accepted 11 November 2007
}

\begin{abstract}
The influence of soil type, slope and drainage on tree growth patterns (density, tree size, crown canopy cover and cork yield) was assessed in a cork oak montado, located in Central-western Portugal, based on a GIS approach followed by field survey. Five soil groups, that is, Arenosols, Regosols, Podzols, Luvisols and Gleysols, combined in three slope classes (flat, undulating and steep) under two different hydromorphic conditions (normal or deficient) were compared based on five cork oak stand parameters using ANOVA and PCA tests. The results showed a clear influence of soil type on cork oak growth patterns (cork yield, basal area, number of trees per hectare, crown canopy cover and circumference at breast height). In Arenosols all parameters showed maximum values and, in contrast, in Gleysols were found the minimum values. For instance, the average of the annual cork production for Gleysols $\left(153 \mathrm{~kg} \mathrm{ha}^{-1}\right.$ year $\left.^{-1}\right)$ was only $70 \%$ of the expected annual cork production of Arenosols $\left(219 \mathrm{~kg} \mathrm{ha}^{-1}\right.$ year $\left.^{-1}\right)$ and the average exploited tree density decreased from 56 trees ha ${ }^{-1}$ in Arenosols to 44 trees ha ${ }^{-1}$ in Gleysols, for an average exploited tree density of 53 trees $\mathrm{ha}^{-1}$ for the study area. Slope also seems to influence the cork oak growth patterns, as significant statistical differences were found for cork oak growth parameters between slope classes: steep slopes decreased the cork production, the tree size (circumference at breast height) and the tree density. An overall PCA test showed that three main soil groups could be identified: (i) Arenosols and Podzols; (ii) Regosols and (iii) Luvisols and Gleysols, showing that the former, which could allow the tree root development, have a positive influence on the cork oak growth. A two-way analysis of variance, for soil type and slope, showed that the cork yield and the exploited tree density are clearly affected by these two factors interaction.
\end{abstract}

(C) 2007 Elsevier B.V. All rights reserved.

Keywords: Quercus suber L.; Montado; Cork yield; Soil; Drainage; Slope; Tree density

\section{Introduction}

The cork oak (Quercus suber L.) woodlands, called montado, are important Mediterranean ecosystems of southern Portugal, and highly social and economically valued nowadays for their cork revenues and livestock production (Pinto-Correia and Mascarenhas, 1999; Montero and Cañellas, 2003; Pereira and Tomé, 2004). This agroforestry system occupies 737,000 ha (DGRF, 2007), and about 683,000 ha (approximately $93 \%$ of the national cork oak area) is located in the southern part of the country. It is characterized by a scattered tree cover with grazing and fallow as undercover, usually in a culture rotation scheme (Pinto-Correia, 1993; Joffre et al., 1999; Carreiras et al., 2006).

\footnotetext{
* Corresponding author. Tel.: +351 21 3653491; fax: +351213645000. E-mail address: augustac@isa.utl.pt (A. Costa).
}

The cork oak montado presents, in average, a tree density of 85 trees ha $^{-1}$ and produces $170 \mathrm{~kg} \mathrm{ha}^{-1}$ year $^{-1}$ of cork (DGRF, 2007). At a regional level, tree density, tree canopy cover and cork production do not follow a uniform pattern, and the rich biological diversity linked to cork oak montado management factors has shaped this ecosystem into a dynamic and high heterogeneous landscape with an increasing mosaic contrast (Antrop, 1993; Blanco et al., 1997; Pereira and Fonseca, 2003). The production system of each cork oak montado, according to the management goals, including the shrub layer management, the cork harvesting periodicity and livestock, evolves different induced stand density and structure (Montero and Cañellas, 2003; Silva and Catry, 2006).

In addition, tree density montado in drier areas, as reported by Joffre et al. (1999) for "dehesas" in Spain, may depend directly on the mean annual rainfall and this feature is a continuous regulation mechanism of the ecosystem for adjusting to water resources to reach new hydrological equilibrium. 
At a local scale, soil conditions seems to partially control some characteristics of cork oak montado, such as the tree density and vitality (Natividade, 1950; Cabral et al., 1992; Diniz, 1994; Joffre et al., 1999; Serrasolses et al., 2004), and have been considered to be the main ecological constrains to the cork oak montado ecosystem sustainability, influencing the vegetation water stress (Cadima et al., 1995; Joffre et al., 1999; Cubera et al., 2004) and the soil aeration (Costello et al., 1990).

Previous studies on montado ecosystem suggested that the intensity of land management practices in relation to soil properties are predisposing factors for the cork oak decline in some regions (Natividade, 1950; Cabral et al., 1993; Ferreira, 2000). Others studies for cork oak montado suggested that the soil properties are the main factor regarding the cork oak stand vitality (Diniz, 1994, 1995). However, no attempt has been made to systematically quantify this influence on the cork oak montado yield, tree size and tree density, as well as to achieve relationships between tree growth and soil properties.

In recent studies reported by Montero et al. (2004), Moreno and Obrador (2007) and Moreno et al. (2007), comprehensive models for dehesa ecosystem functioning were implemented based on established relationships between trees and understory in relation to soil fertility, water dynamics, land use and management practices. However, these studies do not include a major and prior relationship, the one between the soil type and tree growth patterns and generally there is a lack of information in this subject. In this context, in a representative area of cork oak woodlands in Portugal, a study at a stand level was developed in order to characterize the relationship between landscape features (e.g., soil type and slope) and cork oak growth patterns (e.g., tree density and cork yield) and assess the correspondent variability.

This study is a first approach in determining the landscape physical attributes in the cork oak growth patterns and in the cork oak sustainable forestry (management), which was carried out in a region annually producing more than $65 \%$ of national cork production (DGF, 2001). In this region, large estates predominate and due to land tenure characteristics the cork oak land management is oriented to the cork production maximization.

\section{Material and methods}

\subsection{Study area}

The study area is located in a state-owned farm (Companhia das Lezírias) with a total area of 11,071 ha, ranging between $38^{\circ} 56^{\prime} \mathrm{N}-8^{\circ} 45^{\prime} \mathrm{W}$ and $38^{\circ} 45^{\prime} \mathrm{N}-8^{\circ} 42^{\prime} \mathrm{W}$, and between 5 and $50 \mathrm{~m}$ a.s.l., about $50 \mathrm{~km}$ northeast Lisbon, in the centralwestern Portugal (Fig. 1). The climate is of Mediterranean type with some oceanic influence, showing the highest temperatures during summer when rainfall is lowest. Mean annual rainfall is $644 \mathrm{~mm}$, mainly concentrated in late Autumn, Winter and early Spring (refer to the meteorological station of Santo Estevão,

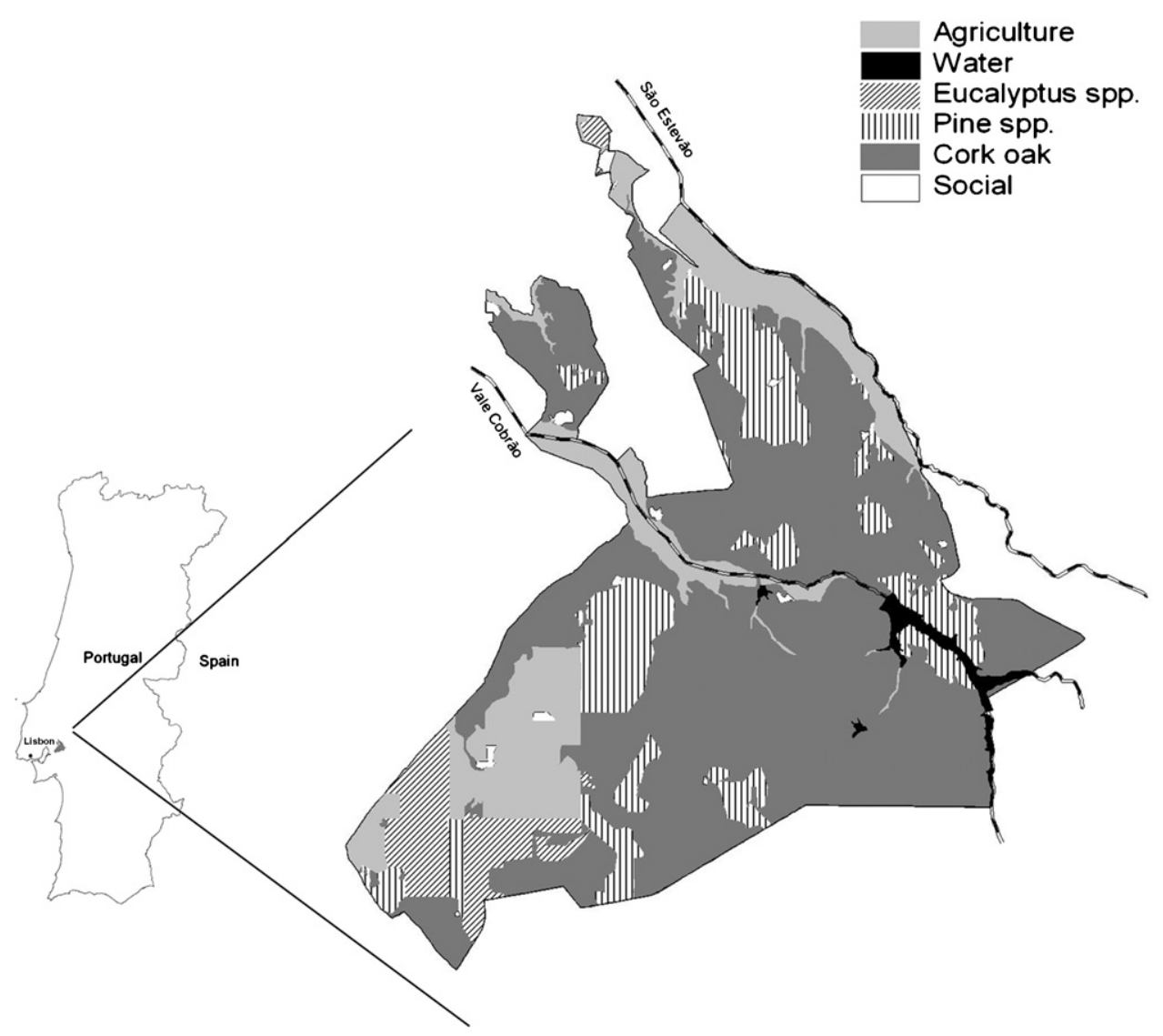

Fig. 1. Location of the study area in Central-Western Portugal. Characteristics of the land use mapped in ortho-rectified digital, infra-red aerial photography of 1995 and 2005. 
located in the study area, for the period 1960-1991), and the mean annual temperature is $16.3{ }^{\circ} \mathrm{C}$ (refer to the meteorological station of Vila Franca de Xira, located approximately $11 \mathrm{~km}$ NW of the site), The mean temperature for the coldest month is $9{ }^{\circ} \mathrm{C}$ (January) and for the hottest month is $22{ }^{\circ} \mathrm{C}$ (July), the mean maximum temperatures in summer reach $28.9^{\circ} \mathrm{C}$ (August) while $5.9^{\circ} \mathrm{C}$ is the mean minimum temperature of the coldest month (January).

According to the land use cover mapped by remote sensing (ortho-rectified digital, infra-red aerial photography acquired in summer 1995 and 2005, 1-m spatial resolution) (Fig. 1) followed by field survey, the cork oak woodlands occupies about 6735 ha and has been managed as a silvo-pastoral system: undercover a scattered tree cover, native pasture areas (using common native grasses like Trifolium sp., Lolium sp. and Medicago sp.) and encroached areas (mainly Ulex parviflorus, Cistus ladanifer, Cistus salvifolius and Lavandula stoechas), intercropped with grazing areas (Triticum $\times$ Secale), to control shrub encroachment and to obtain fodder complement for cattle.

The cork oak woodlands resulted of assist natural regeneration complemented with local artificial seeding and plantation resulting in an uneven-aged stand. The trees are pruned in juvenile ages, before the beginning of the 9-year periodical cork cycle extraction, at the 20-25 years of age. Thinning occurs regularly, only to eliminate dead trees. According to a previous cork oak forest inventory with the establishment of 460 plots, the mean tree density $(N)$ was about 62 trees ha ${ }^{-1}$, the basal area $(G)$ was $3.2 \mathrm{~m}^{2} \mathrm{ha}^{-1}$ and an average annual cork production of $110 \mathrm{~kg} \mathrm{ha}^{-1}$ year $^{-1}$ was to be expected. Cork oak montado structure shows that about $70 \%$ of cork oaks are already in production; nevertheless it is a young cork oak montado, with a mortality of 0.5 trees ha $^{-1}$ year $^{-1}$ (Costa, 1990; Sousa, 1997).

According to the Geologic Map $(1: 50,000)$ in the study area only geologic sedimentary formations occur. They are (i) Quaternary sands (recent sands), (ii) Pleistocene formations (river terraces represented by sands and sandstones with clay beds), and (iii) Miocene-Pliocene formations (mostly sandstones), which corresponds to the "Complexo Gresoso de Coruche” (Zbyszewski, 1964; Zbyszewski and Ferreira, 1969).

The major cork oak area is flat and gentle undulating, with slopes ranging mainly between 0 and 5\%. Greater slopes only are observed in small areas of the Miocene-Pliocene formations near the Vale Cobrão (cross the center of the estate) and the São Estevão (cross the East limit of farm) rivers, where some gully soil erosion could occur.

The soils are mostly related to the nature of the geological substrate. On sand formations, soils are mostly Haplic Arenosols and Entic Podzols, which show deep sandy layers of high permeability and low water storage capacity. Endoleptic and Haplic Regosols are developed on sandstones at distinct depths. Stagnic Luvisols, located in flat areas and also developed on sandstones where beds of clays occur, show an argic horizon which determines, in wet periods, slow water drainage. Luvic Gleysols are also developed on sandstones with clay beds and located in areas with null or insufficient external drainage. In restrict areas, in the border of water-lines, Fluvisols occur. Soils of the study area are mostly slightly acid and low in nutrients and organic matter (Cardoso, 1965; Gusmão and Madeira, 1986). These soils can be grouped in systems with strong differences: deep soils with sandy texture (Arenosols and Podzols), soils with a Bt horizon and deficient drainage (Luvisols and Gleysols) and soils with intermediate texture and variable depth (Regosols). Thus, soils were not subjected to specific measurements.

\subsection{Methodology and data analysis}

The study was conducted through GIS methodology on the cork oak area cover overlaid by several layers comprising: (i) the soil map cover with the Reference Soil Groups (WRB, 2006) (Fig. 2); (ii) the slope classification (Flat: 0-5\%, Undulating: 6$15 \%$ and Steep: $>16 \%$ ) and (iii) the hydromorphic soil conditions (normal or deficient drainage), all based and adapted from the geo-referenciated digital cover of Portuguese Soil Map at 1/50,000 scale (SROA,1963). The Reference Soil Groups were adapted from the Portuguese Soil Classification (Cardoso, 1965) and were applied in this study in order to use a standard denomination for soils, considered important at communication in an international level, that simultaneously emphasize soil features and their relationship with soil forming processes, key factors for land use management.

The tree canopy cover was mapped on the cork oak area cover by digital aerial photo-interpretation and classified in three classes of ground horizontal projection of tree crown area as percentage of total area (clear: $<25 \%$, open: $25-50 \%$ and dense: $>50 \%$ ). This cover was overlaid the cork oak woodlands limits (Fig. 3). The characteristics of spatial distribution of cork oak in the study area and the overall accuracy in the juxtaposition of patches limits of soil type and tree canopy classes were visually assessed.

The methodology of the cork oak forest inventory followed a systematic sampling design using a line plot system defined by a compass lines established at a uniform spacing of $250 \mathrm{~m}$ and by locating $200 \mathrm{~m}^{2}$ circular plots at $250 \mathrm{~m}$ intervals along the lines in a filtered cork oak area layer, classified in the 2 nd or 3 rd tree canopy class. Each sample plot was represented by a point in a spatial mesh linked to the database of attributes of the soil layers and tree canopy layer.

The cork oak sampling comprised the measurement of a total 1014 plots that were filtered and only plots with a minimum of 5 trees ha ${ }^{-1}$ were kept for analysis avoiding higher variance and variability on the sample. A total of 888 plots were selected corresponding to a sampling area of 178 ha, about $2.7 \%$ of total cork oak area (Table 1), corresponding each plot to a RSG (WRB, 2006).

For each cork oak plot, in all trees with circumference at breast height (CAP) equal or superior to $70 \mathrm{~cm}$, was registered the cork oak circumference $\left(\mathrm{CAP}_{1.30 \mathrm{~m}}\right)$, the cork stripping status (virgin or debarked) and the cork extraction year (Year). The exploited tree density in number of exploited trees per hectare $(N)$ was calculated as the sum of exploited trees in the plot proportional to hectare, the maximum circumference at breast height $\mathrm{CAP}_{\max 1.30 \mathrm{~m}}$, as the maximum $\mathrm{CAP}_{1.30 \mathrm{~m}}$ in the plot, the mean circumference at breast height, $\mathrm{CAP}_{\text {mean } 1.30 \mathrm{~m}}$ as 


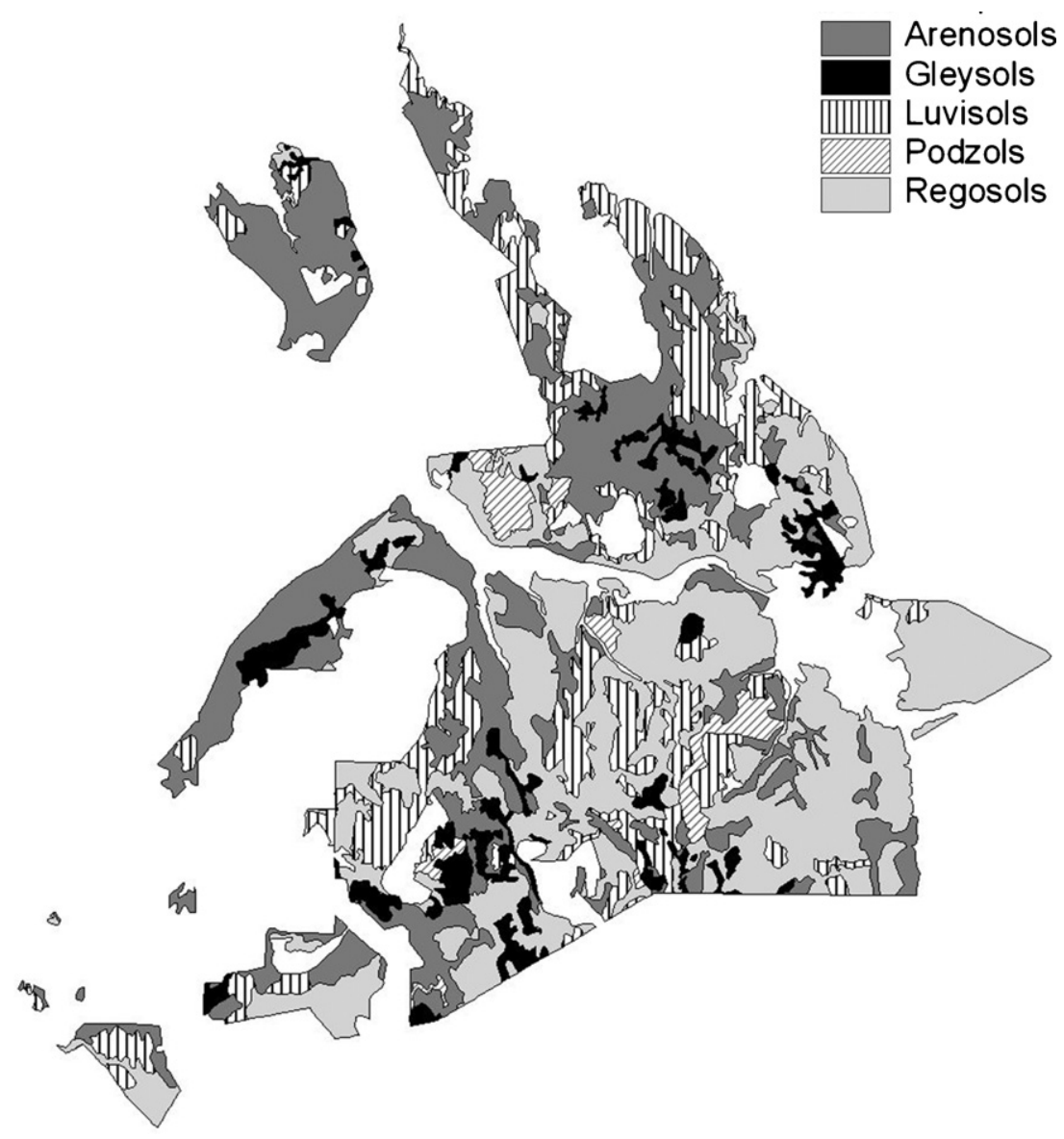

Fig. 2. Distribution of Reference Soil Groups (RSG): Arenosols, Regosols, Podzols, Luvisols and Gleysols in the study area.

the average circumference at breast height in the plot, the exploited basal area $(G)$ as the sum of sectional area in the plot proportional to hectare.

The cork production (Yield) was estimated applying a cork yield model (Costa, 1990) that predicts the stand cork yield with the cork with an age of 9 years as a linear function of the stand basal area, Yield $=-98.177+315.87 G$, where Yield is the cork yield, in $\mathrm{kg} \mathrm{ha}^{-1}$ and $G$ is the basal area in $\mathrm{m}^{2} \mathrm{ha}^{-1}$ (Montero, 1987; Costa, 1990; Montero et al., 1996; Cañellas and Montero, 2002). If cork age is under 9 years an algorithm was developed to estimate the basal area with cork with 9 years integrating one tree level cork growth model for this stand (Costa et al., 2002), $\mathrm{cg}=-0.0252 \mathrm{ca}^{2}-0.158 \mathrm{ca}+5.1094$, where $\mathrm{cg}(\mathrm{mm})$ is the cork growth and ca is the cork age (number of years after the year of the cork extraction, Year) and the calculations of the correspondent total 9-year tree diameter.

The statistical analysis performed with SSPS ${ }^{\circledR}$ package software (SPSS, 2004) was an exploratory analysis of data in order to characterize the cork oak growth parameters and its variability. Also multisample hypotheses, one-way and twoway analysis of variance were made to identify univariate and multivariate effects of physical factors in the cork oak growth patterns and the Principal Components Analysis (PCA) was used to identify the principal components (variables and factors) depicting the cork oak montado yield, structure and density.

\section{Results}

\subsection{Tree density, tree size and cork yield in relation to soil groups}

According to the soil map of the study area, almost all cork oak area (99\%) was distributed by five Reference Soil Groups (RSG) (WRB, 2006): Arenosols (AR), Regosols (RG), Podzols (PZ), Luvisols (LV) and Gleysols (GL) (Fig. 2). The AR and RG represented more than $70 \%$ of total cork oak area, LV was the third most representative soil, with $18 \%$ of cork oak area, GL only had 7\% and PZ occupied 3\% (Table 1). To each RSG correspond a different number of cork oak inventory plots, that is, the larger soil units area have higher number of sampled plots. The sampled area ranged between $1.8 \%$ (Gleysols) and $3.1 \%$ (Regosols) (Table 1).

Based on the visual inspection of digital aerial photographs on the tree canopy cover classes, the total cork oak area was distributed by tree canopy cover class. This distribution shows that only approximately 54\% of cork oak area has more than $50 \%$ canopy cover which is a characteristic of the agroforestry system cork oak montado (Table 2).

The spatial distribution of cork oak showed differences between the five RSG. In the Gleysols almost half of cork oak area is a clear montado $(<25 \%$ canopy cover $)$. The juxtaposition of patches of Gleysols with clear montado 


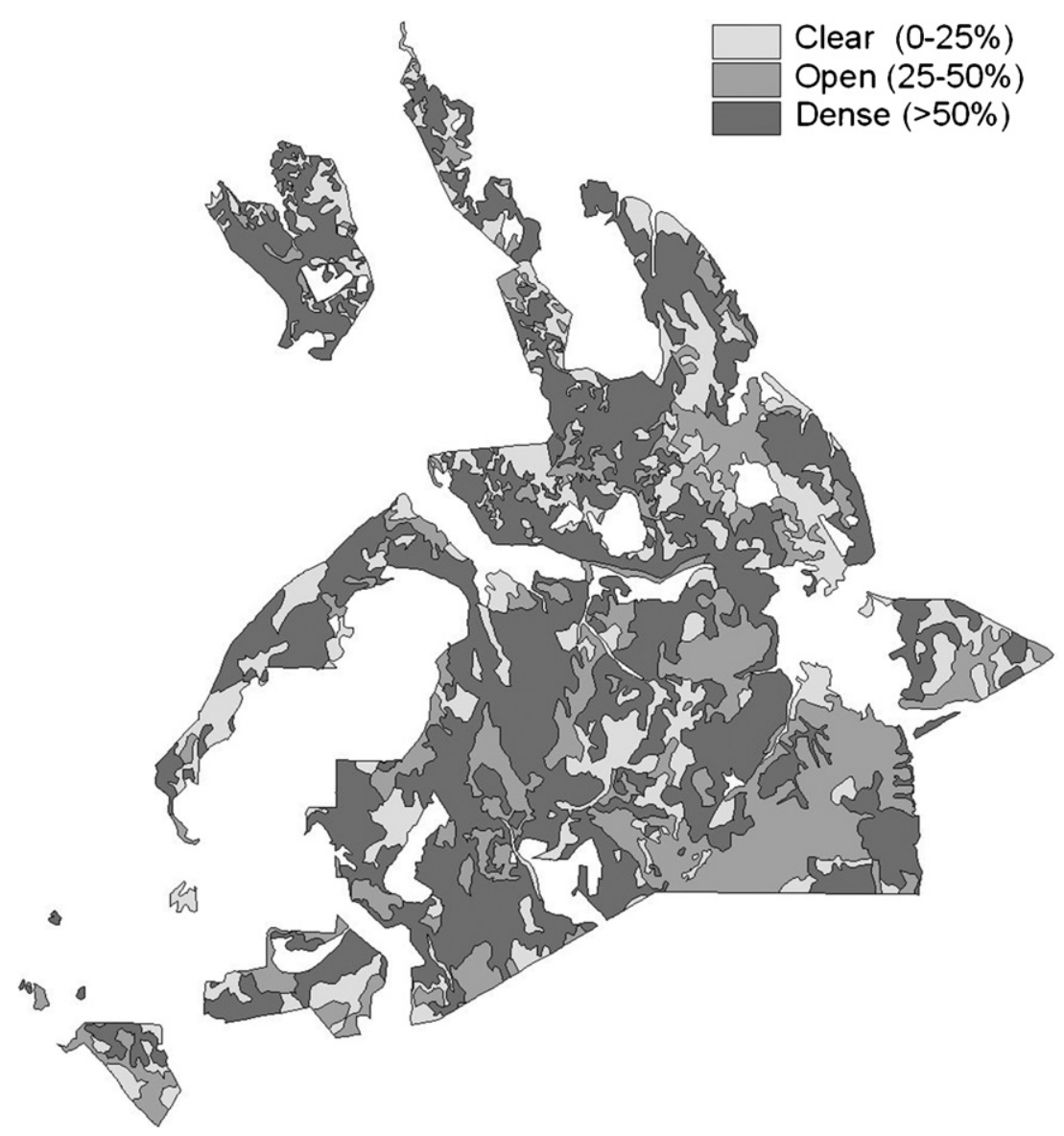

Fig. 3. Cork oak canopy cover map for the study area. Cork oak canopy cover as ground horizontal projection of the crown area in percentage of total area: clear montado (0-25\%), open montado (25-50\%) and dense montado (>50\%).

( $<25 \%$ canopy cover) can be visually detected comparing Figs. 2 and 3. In contrast, in Arenosols about 67\% of cork oak area is a dense montado ( $>50 \%$ canopy cover). A decreasing trend in the tree canopy cover can be observed from the Arenosols and Podzols to Regosols, Luvisols and Gleysols (Table 2).

The results for tree density in relation to soil obtained with the GIS approach (cork oak canopy cover, Table 2) were consistent with the results collected from the cork oak forest inventory (number of trees per hectare, Table 3 ) showing that in the Gleysols the cork oak montado is predominantly clear or open which corresponds to the lowest exploited tree density $(N)$ of about 44 trees ha ${ }^{-1}$.
According to the field survey the mean values obtained for all measured variables at tree plots (tree density, basal area, mean and maximum circumference at breast height and cork production) differed between RSG independently of the great variability between cork oak plots (Table 3). The ANOVA tests performed for the effect of the soil factor on the tree density $(N)$, maximum circumference at breast height $\left(\mathrm{CAP}_{1.30 \mathrm{~m}}\right)$ and cork yield (Yield) showed that the null hypothesis was rejected at all cases $(p \leq 0.001)$ and it was concluded that there were significant statistical differences between RSG.

The mean value for cork yield in the study area was $1670 \mathrm{~kg} \mathrm{ha}^{-1}$, which corresponds to an annual cork production

Table 1

Distribution of the dominant Reference Soil Groups in the study area, based on both the soil map (Fig. 2) and the forest inventory

\begin{tabular}{|c|c|c|c|c|c|c|}
\hline $\begin{array}{l}\text { Reference soil } \\
\text { groups }\end{array}$ & Area (ha) & $\begin{array}{l}\text { Percentage of cork } \\
\text { oak area }(\%)\end{array}$ & $\begin{array}{l}\text { Number of forest } \\
\text { inventory plots }\end{array}$ & $\begin{array}{l}\text { Percentage of total } \\
\text { number of plots }(\%)\end{array}$ & $\begin{array}{l}\text { Total sampled } \\
\text { (ha) }\end{array}$ & Area $(\%)$ \\
\hline Arenosols (AR) & 2164 & 32.1 & 292 & 32.9 & 58 & 2.7 \\
\hline Regosols (RG) & 2594 & 38.5 & 400 & 45.0 & 80 & 3.1 \\
\hline Podzols (PZ) & 215 & 3.2 & 27 & 3.0 & 5 & 2.5 \\
\hline Luvisols (LV) & 1234 & 18.3 & 127 & 14.3 & 25 & 2.1 \\
\hline Gleysols (GL) & 476 & 7.1 & 42 & 4.7 & 8 & 1.8 \\
\hline Total & 6683 & 99.2 & 888 & 100.0 & 178 & 2.7 \\
\hline
\end{tabular}


Table 2

Proportion of cork oak canopy cover classes according to the dominant Reference Soil Groups in the study area (Fig. 3)

\begin{tabular}{lrcr}
\hline Reference soil groups & \multicolumn{3}{l}{$\begin{array}{l}\text { Area (ha) and percentage of cork oak area (\%) by tree } \\
\text { canopy cover classes }\end{array}$} \\
\cline { 2 - 4 } & Clear $(<25 \%)$ & Open $(25-50 \%)$ & Dense $(>50 \%)$ \\
\hline Arenosols (AR) & $333(15.4 \%)$ & $372(17.2 \%)$ & $1459(67.4 \%)$ \\
Regosols (RG) & $359(13.8 \%)$ & $802(30.9 \%)$ & $1434(55.3 \%)$ \\
Podzols (PZ) & $44(20.3 \%)$ & $19(8.9 \%)$ & $152(70.8 \%)$ \\
Luvisols (LV) & $453(36.7 \%)$ & $339(27.4 \%)$ & $442(35.8 \%)$ \\
Gleysols (GL) & $232(48.8 \%)$ & $143(30.0 \%)$ & $101(21.2 \%)$ \\
Total & $1421(21.3 \%)$ & $1674(25.0 \%)$ & $3588(53.7 \%)$ \\
\hline
\end{tabular}

$186 \mathrm{~kg} \mathrm{ha}^{-1}$ year $^{-1}$, being slightly superior to the expected average production for the study area. The biggest trees with $189 \mathrm{~cm}$ average $\mathrm{CAP}_{\max 1.30 \mathrm{~m}}$ and maximum cork production (1968 $\mathrm{kg} \mathrm{ha}^{-1}$, to which correspond to an annual productivity of $219 \mathrm{~kg} \mathrm{ha}^{-1}$ year $^{-1}$ ) were found in Arenosols. In the Gleysols were located the smaller trees (with mean maximum circumference of $162 \mathrm{~cm}$ ) and the lowest cork yield was expected (average $1378 \mathrm{~kg} \mathrm{ha}^{-1}$ ), showing a negative difference of $30 \%$ in annual production in relation to Arenosols (Table 3).

The mean exploited tree density $(N)$ for the study area was in average 53 trees ha ${ }^{-1}$ and only in Gleysols and Luvisols the density was lower with 44 and 47 trees ha ${ }^{-1}$, respectively, a reduction between 11 and $17 \%$ in the number of exploited trees per hectare (Table 3).

The mean basal area $(G)$ for the study area was $5.3 \mathrm{~m}^{2} \mathrm{ha}^{-1}$, which is slightly superior to the expected average exploited basal area. The minimum value of $G$ was observed in Gleysols with $4.6 \mathrm{~m}^{2} \mathrm{ha}^{-1}$ and the maximum value in Arenosols, $6.3 \mathrm{~m}^{2} \mathrm{ha}^{-1}$ (Table 3).

The Tukey's multiple comparison tests were performed for three variables $N$, Yield and $\mathrm{CAP}_{\max 1.30 \mathrm{~m}}$ and the results showed significant difference among RSG groups based on tree dimension $\left(\mathrm{CAP}_{\max 1.30 \mathrm{~m}}\right)$, tree density $(N)$ and cork yield (Yield). Two separated soil groups were found for all variables: one with Podzols and Arenosols and other with Gleysols and Luvisols, Also for all variables a major overlapping occurred in the intermediate group of Regosols (Table 3).

\subsection{Tree density, structure and cork yield in relation to slope and drainage}

The results observed for cork oak parameters (tree density, basal area, mean and maximum circumference at breast height and cork production) in relation to slope (Table 4) showed that for steep slopes all the mean values decreases. For instance, in flat slopes cork yield, exploited tree density and maximum $\mathrm{CAP}_{\max 1.30 \mathrm{~m}}$ are about $1709 \mathrm{~kg} \mathrm{ha}^{-1}, 52$ trees ha ${ }^{-1}$ and $176 \mathrm{~cm}$, respectively, in contrast with the values found for steep slopes of $1217 \mathrm{~kg} \mathrm{ha}^{-1}, 44$ trees $\mathrm{ha}^{-1}$ and $159 \mathrm{~cm}$, respectively (Table 4).

Considering only the slope factor, the ANOVA tests performed for the exploited tree density $N$, showed that the null hypothesis was rejected (at an alpha level of 0.05) and it was concluded that there were significant statistical differences between the slope classes. The Tukey's multiple comparison tests for this variable showed significant difference among groups (Table 4). At the soil level, only in Regosols were found statistically significant mean differences between exploited tree densities (at an alpha level of 0.05). In this soil the undulating class $(6-15 \%)$ presented the maximum mean value for $N$ equal to 62 trees ha ${ }^{-1}$, the steep slope class showed the minimum value of 44 trees ha ${ }^{-1}$ and the flat class showed the mean values of 52 trees $\mathrm{ha}^{-1}$.

In relation to Yield and $\mathrm{CAP}_{\max 1.30 \mathrm{~m}}$ the ANOVA tests, similarly to exploited tree density, showed that there were significant statistical differences between the slope classes. The Tukey's multiple comparison tests for these variables showed significant difference among groups. Two groups were separated, the flat slope class $(0-5 \%)$ and the steep slope class $(<16 \%)$ and an overlapping occurred in the intermediate group the undulating slope class (6-15\%) (Table 4). At the soil level, in Regosols a significant statistical difference $(p<0.05)$ was found for tree maximum circumference $\left(\mathrm{CAP}_{\max 1.30 \mathrm{~m}}\right)$ and for this RSG and for Luvisols apparently seems to have some negative influence of slope on cork production ( $p=0.069$ and 0.120 , respectively).

The deficient drainage in the soil seems to influence negatively all cork oak variables (Table 4), for instance average cork production, ranged from 1692 to $1548 \mathrm{~kg} \mathrm{ha}^{-1}$ (a decrease of more than $8 \%$ in cork production) and basal area $(G)$ decreased from 5.3 to $4.9 \mathrm{~m}^{2} \mathrm{ha}^{-1}$. However, no statistically

Table 3

Values of cork yield (Yield), exploited tree density $(N)$, circumference at breast height $\left(\mathrm{CAP}_{1.30 \mathrm{~m}}\right)$, mean and maximum and exploited basal area $(G)$ and discriminated by soil (RSG)

\begin{tabular}{|c|c|c|c|c|c|}
\hline \multirow[t]{2}{*}{ Stand characteristics } & \multicolumn{5}{|c|}{ Reference soil groups (RSG) } \\
\hline & Arenosols (AR) & Podzols (PZ) & Gleysols (GL) & Luvisols (LV) & Regosols (RG) \\
\hline$N\left(\right.$ no. ha $\left.{ }^{-1}\right)$ & $56^{\mathrm{a}} \pm 23.6(292)$ & $56^{\mathrm{a}} \pm 26.5(27)$ & $44^{\mathrm{b}} \pm 15.9(42)$ & $47^{\mathrm{b}} \pm 18.4(127)$ & $55^{\mathrm{a}, \mathrm{b}} \pm 27.0(400)$ \\
\hline$G\left(\mathrm{~m}^{2} \mathrm{ha}^{-1}\right)$ & $6.3 \pm 2.8(292)$ & $5.5 \pm 2.6(27)$ & $4.6 \pm 6.1(42)$ & $4.8 \pm 2.4(127)$ & $4.8 \pm 2.1(400)$ \\
\hline $\mathrm{CAP}_{\text {mean } 1.30 \mathrm{~m}}(\mathrm{~cm})$ & $124 \pm 25.7(292)$ & $116 \pm 17.4(27)$ & $115 \pm 23.7(42)$ & $118 \pm 23.7(127)$ & $110 \pm 19.8(400)$ \\
\hline $\mathrm{CAP}_{\max 1.30 \mathrm{~m}}(\mathrm{~cm})$ & $189^{\mathrm{a}} \pm 47.8(292)$ & $170^{\mathrm{a}} \pm 26.1$ & $162^{\mathrm{b}} \pm 38.6(42)$ & $169^{b} \pm 39.9$ & $161^{\mathrm{a}, \mathrm{b}} \pm 38.2(400)$ \\
\hline Yield $\left(\mathrm{kg} \mathrm{ha}^{-1}\right)$ & $1968^{\mathrm{a}} \pm 909.6(292)$ & $1700^{\mathrm{a}} \pm 821.5$ & $1378^{\mathrm{b}} \pm 792.3(42)$ & $1497^{b} \pm 795.7$ & $1537^{\mathrm{a}, \mathrm{b}} \pm 765.5(400)$ \\
\hline
\end{tabular}

Values of mean \pm standard deviation (number of plots).

Superscript letters ( $\mathrm{a}$ and $\mathrm{b}$ ) denote homogeneous subsets with significant means difference, $p<0.05: \mu_{\mathrm{AR}}=\mu_{\mathrm{PZ}} \neq \mu_{\mathrm{RG}}=\mu_{\mathrm{LV}}=\mu_{\mathrm{GL}}$ (Tukey multiple comparison test). 
Table 4

Values of cork yield (Yield), exploited tree density $(N)$, circumference at breast height $\left(\mathrm{CAP}_{1.30 \mathrm{~m}}\right)$, mean and maximum and exploited basal area $(G)$ and discriminated by slope and drainage

\begin{tabular}{|c|c|c|c|c|c|}
\hline \multirow[t]{2}{*}{ Stand characteristics } & \multicolumn{3}{|l|}{ Slope $^{*}$} & \multicolumn{2}{|l|}{ Drainage $^{* *}$} \\
\hline & $(0-5 \%)$ & $(6-15 \%)$ & $(>16 \%)$ & Normal & Deficient \\
\hline$\overline{N\left(\text { no. } \text { ha }^{-1}\right)}$ & $52^{\mathrm{a}} \pm 22.9(669)$ & $60^{b} \pm 30.5(178)$ & $44^{\mathrm{c}} \pm 17.2(41)$ & $54^{\mathrm{a}} \pm 25.3(754)$ & $49^{\mathrm{b}} \pm 19.7(134)$ \\
\hline$G\left(\mathrm{~m}^{2} \mathrm{ha}^{-1}\right)$ & $5.4 \pm 2.5(669)$ & $5.1 \pm 2.5(178)$ & $4.1 \pm 1.7(41)$ & $5.3 \pm 2.5(754)$ & $4.9 \pm 2.6(134)$ \\
\hline $\mathrm{CAP}_{\text {mean } 1.30 \mathrm{~m}}(\mathrm{~cm})$ & $118 \pm 23.4(669)$ & $111 \pm 23.2(178)$ & $110 \pm 17.2(41)$ & $117 \pm 23.5(754)$ & $115 \pm 22.4(134)$ \\
\hline $\mathrm{CAP}_{\max 1.30 \mathrm{~m}}(\mathrm{~cm})$ & $176^{\mathrm{a}} \pm 44.1$ & $161^{\mathrm{a}, \mathrm{b}} \pm 40.3(178)$ & $159^{\mathrm{b}} \pm 30.7(41)$ & $173^{\mathrm{a}} \pm 43.2(754)$ & $168^{\mathrm{a}} \pm 43.8$ \\
\hline Yield $\left(\mathrm{kg} \mathrm{ha}^{-1}\right)$ & $1709^{\mathrm{a}} \pm 859.2(669)$ & $1629^{\mathrm{a}, \mathrm{b}} \pm 833.7$ & $1217^{\mathrm{b}} \pm 551.2$ & $1692^{\mathrm{a}} \pm 844.6$ & $1548^{\mathrm{a}} \pm 860.8$ \\
\hline
\end{tabular}

Values of mean \pm standard deviation (number of plots).

${ }^{*}$ Superscript letters $\left(\mathrm{a}-\mathrm{c}\right.$ ) denote homogeneous subsets with significant means difference, $p<0.05: \mu_{0-5 \%} \neq \mu_{6-15 \%} \neq \mu_{>16 \%}$ (Tukey multiple comparison test).

** Superscript letters ( $\mathrm{a}$ and $\mathrm{b}$ ) denote homogeneous subsets with significant means difference, $p<0.05: \mu_{\text {normal }} \neq \mu_{\text {deficient }}$ (Tukey multiple comparison test).

significant differences were observed between normal and deficient drainage (at an alpha level of 0.05) for these two variables.

The ANOVA tests performed only showed that the null hypothesis was rejected (at an alpha level of 0.05) for the exploited tree density $N$, and it was concluded that there were significant statistical differences between tree density in normal and deficient drainage conditions. In normal conditions the average exploited tree density is 54 trees ha ${ }^{-1}$, which is significantly superior to density in deficient soil drainage conditions where average tree density is 49 trees ha $^{-1}$ (Table 4$)$.

\subsection{Identifying factors or variables for density, structure and cork yield}

As significant differences were concluded among different soil types and slope classes for cork production (Yield), tree dimension $\left(\mathrm{CAP}_{\max 1.30 \mathrm{~m}}\right)$ and exploited tree density $(N)$ a twoway variance analysis for these factors was made based on a random data sub-sample with proportional replication of data in which was considered the five RSG and two slope classes, flat and undulating (Table 5).

The results showed that for all considered variables there is a main effect of soil type and slope in the cork oak stand characteristics. In addition, for the cork yield and tree density there is an interaction between these two effects which means that the effect of the soil type is not independent of the effect of a particular slope class (Table 5). In relation to the tree dimension the soil type $\times$ slope effect showed to be not significant enough to reject the null hypothesis $(p=0.31)$ which means that the dimension of trees seems to be mainly affected by the soil type and clearly there is no interaction of the two effects (Table 5).

In contrast to the maximum circumference at breast height $\left(\mathrm{CAP}_{\max 1.30 \mathrm{~m}}\right)$, the cork yield (Yield) and the exploited tree density $(N)$ showed a strong variation between the two slope classes (flat and undulating). For instance, in Podzols in average the $\mathrm{CAP}_{\max 1.30 \mathrm{~m}}$ only varies between 172 and $169 \mathrm{~cm}$ and cork yield and tree density varies between 947 and $1745 \mathrm{~kg} \mathrm{ha}^{-1}$ and 38 and 66 trees ha ${ }^{-1}$, respectively, for the undulating and the flat class (Table 6), that is, the average values of the former are almost half of the ones from the latter.
In the PCA analysis all five cork oak variables were selected and standardized (centered and reduced) and the data set was represented by a matrix of 5 variables $\times 888$ plots. The results showed that Factors F1 and F2 explained about $93 \%$ of total variance and the three factors, F1, F2 and F3 explained $97 \%$ of the variance within the variables (Table 7).

In relation to soil, the first component, F1, showed positive loads related to the presence of deep soils with sandy textures of high permeability and promoting root development like Arenosols and Podzols and negative loads representing soils with deficient drainage as in Luvisols and Gleysols (Fig. 4).

Table 5

Two-way factorial analysis of variance for: (a) exploited tree density $(N)$; (b) cork yield (Yield) and (c) maximum circumference at breast height (CAP$\max 1.30 \mathrm{~m}$ )

\begin{tabular}{|c|c|c|c|c|}
\hline Source of variation & Sum of squares (SS) & $\mathrm{DF}$ & Mean square (MS) & $\mathrm{F}$ \\
\hline \multicolumn{5}{|c|}{ Exploited tree density } \\
\hline Total & $170,772.000$ & 363 & & \\
\hline Model & $12,669.968$ & 9 & 1407.774 & $3.15^{* *}$ \\
\hline Soil type & 4632.293 & 4 & 1158.073 & $2.59^{*}$ \\
\hline Slope & 2570.737 & 1 & 2570.737 & $5.76^{*}$ \\
\hline $\begin{array}{l}\text { Soil type } \\
\times \text { slope }\end{array}$ & 5466.939 & 4 & 1366.735 & $3.06^{*}$ \\
\hline Error & $158,102.032$ & 354 & 446.616 & \\
\hline \multicolumn{5}{|l|}{ Cork yield } \\
\hline Total & $113,997,997.030$ & 363 & & \\
\hline Model & $25,019,103.648$ & 9 & $2,779,900.405$ & $11.06^{* * * *}$ \\
\hline Soil type & $12,206,221.949$ & 4 & $3,051,555.487$ & $12.14^{* * * *}$ \\
\hline Slope & $8,091,617.886$ & 1 & $8,091,617.886$ & $32.20^{* * *}$ \\
\hline $\begin{array}{l}\text { Soil type } \\
\times \text { slope }\end{array}$ & $4,718,263.813$ & 4 & $1,179,565.953$ & $4.69^{* *}$ \\
\hline Error & $88,978,893.382$ & 354 & $251,352.806$ & \\
\hline \multicolumn{5}{|c|}{ Maximum circumference at breast height } \\
\hline Total & $490,204,964$ & 363 & & \\
\hline Model & $54,985,996$ & 9 & $6,109,555$ & $4.97^{* * * *}$ \\
\hline Soil type & $44,473,980$ & 4 & $11,118,495$ & $9.05^{* * * *}$ \\
\hline Slope & $9,001,147$ & 1 & $9,001,147$ & $7.32^{*}$ \\
\hline $\begin{array}{l}\text { Soil type } \\
\times \text { slope }\end{array}$ & $1,510,869$ & 4 & 377,717 & 0.31 n.s. \\
\hline Error & $435,218,968$ & 354 & $1,229,432$ & \\
\hline
\end{tabular}

n.s. not significant.

${ }^{*} p<0.05$.

*** $p<0.005$.

**** $p<0.001$. 
Table 6

Variation with soil type and slope classes of the exploited tree density $(N)$; cork yield (Yield) and maximum circumference at breast height $\left(\mathrm{CAP}_{\text {max } 1.30 \mathrm{~m})}\right.$

\begin{tabular}{|c|c|c|c|c|c|c|}
\hline \multirow[t]{2}{*}{ Slope classes } & \multirow[t]{2}{*}{ Stand characteristics } & \multicolumn{5}{|c|}{ Reference soil groups (RSG) } \\
\hline & & Arenosols (AR) & Podzols (PZ) & Gleysols (GL) & Luvisols (LV) & Regosols (RG) \\
\hline Flat & $\begin{array}{l}N\left(\text { no ha }{ }^{-1}\right) \\
\text { Yield }\left(\mathrm{kg} \mathrm{ha}^{-1}\right) \\
\mathrm{CAP}_{\max 1.30 \mathrm{~m}}(\mathrm{~cm})\end{array}$ & $\begin{array}{c}52 \pm 2 \\
1844 \pm 58 \\
191 \pm 4\end{array}$ & $\begin{array}{c}66 \pm 9 \\
1745 \pm 224 \\
172 \pm 16\end{array}$ & $\begin{aligned} 41 & \pm 7 \\
1270 & \pm 159 \\
154 & \pm 11\end{aligned}$ & $\begin{aligned} 52 & \pm 5 \\
1515 & \pm 112 \\
166 & \pm 8\end{aligned}$ & $\begin{array}{c}57 \pm 2 \\
1718 \pm 41 \\
172 \pm 3\end{array}$ \\
\hline Undulating & $\begin{array}{l}N\left(\text { no ha }{ }^{-1}\right) \\
\text { Yield }\left(\mathrm{kg} \mathrm{ha}^{-1}\right) \\
\mathrm{CAP}_{\max 1.30 \mathrm{~m}}(\mathrm{~cm})\end{array}$ & $\begin{array}{c}58 \pm 4 \\
1898 \pm 92 \\
184 \pm 6\end{array}$ & $\begin{array}{l}38 \pm 15 \\
947 \pm 355 \\
169 \pm 25\end{array}$ & $\begin{aligned} 33 & \pm 11 \\
625 & \pm 251 \\
123 & \pm 18\end{aligned}$ & $\begin{array}{c}33 \pm 7 \\
968 \pm 177 \\
155 \pm 12\end{array}$ & $\begin{array}{c}48 \pm 3 \\
1261 \pm 65 \\
161 \pm 5\end{array}$ \\
\hline
\end{tabular}

Mean and the $95 \%$ confidence interval.

Table 7

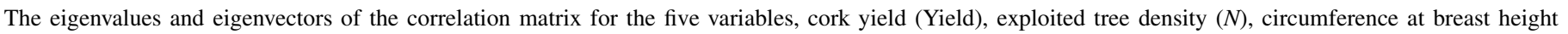
$\left(\mathrm{CAP}_{1.30 \mathrm{~m}}\right)$, mean and maximum and exploited basal area $(G)$ on the 888 plots

\begin{tabular}{|c|c|c|c|c|c|c|}
\hline \multirow[t]{2}{*}{ Principal component } & \multirow[t]{2}{*}{ Eigenvalue } & \multicolumn{5}{|c|}{ Eigenvector, coefficient of } \\
\hline & & $N$ & $\mathrm{CAP}_{\max 1.30 \mathrm{~m}}$ & $\mathrm{CAP}_{\text {mean } 1.30 \mathrm{~m}}$ & Yield & $G$ \\
\hline 1 & $3.15(63 \%)$ & 0.16 & 0.26 & 0.21 & 0.30 & 0.31 \\
\hline 2 & $1.48(30 \%)$ & 0.58 & -0.30 & -0.47 & 0.17 & 0.11 \\
\hline 3 & $0.25(5 \%)$ & & & & & \\
\hline 4 & $0.7(2 \%)$ & & & & & \\
\hline 5 & $0.0(0 \%)$ & & & & & \\
\hline
\end{tabular}

The Regosols present a negative load for this first component F1 but a positive load for the second component F2, as in this soil group heterogeneous physical characteristics of (Endoleptic and Haplic) Regosols profile, as texture and depth, directly related to slope, could influence the cork oak density, size and the cork production. Nevertheless, the first component seems to be mainly related to the soil type and drainage (Fig. 4a).

The PCA scatterplots for slope and drainage showed distinct groups and the flat and steep slope seems to oppose the F1 and F2 values similarly to normal and deficient drainage (Fig. 4b and c). For the two factors soil type and slope a distinct group with Arenosols and Podzols can be separated with the later being severely affected by slope (Fig. $4 \mathrm{~d}$ ).

\section{Discussion}

Under the same climatic conditions, the soil properties, like texture, nature of parent material and soil depth or profile morphology, directly influence the tree growth in forest and agroforestry systems, as tree (shoot) growth is indexed to the root growth and functioning (Burger and Kelting, 1999; Joffre et al., 1999; Fisher and Binkley, 2000). The soil-site relationships are clear in the study area. Three distinct soil groups could be identified as promoting differently the cork oak growth: (i) Arenosols (AR) and Podzols (PZ); (ii) Regosols (RG) and (iii) Luvisols (LV) and Gleysols (GL). In the former cork oak densities, size and cork yields showed the highest values, while in the latter the lowest cork oak parameters were observed.

Haplic Arenosols (sandy soils) are characterized by having low nutrient and low water storage capacity, a serious constrain to cork oak growth mostly in dryer areas. However, based on the results obtained for cork production, the cork oak size, tree density and crown canopy cover showed the maximum values in these soils. This positive influence on cork oak growth should be related to its high profile depth and unconsolidated parent material, allowing a deep root development and consequently the easy access to groundwater, the main reliable water source for evergreen oaks in Mediterranean woodlands (Costa et al., 2002; Moreno et al., 2005; David et al., 2007) either through direct uptake by deep roots or absorption of hydraulically lifted water by shallow roots (David et al., 2007). Arenosols in the study area should allow an increased cork oak effective rooting depth and should allow an increased availability in soil moisture and the maintenance of metabolically active roots during summer season (Fisher and Binkley, 2000; Costa et al., 2002; Moreno et al., 2005).

The Podzols (Entic Podzols) in the study area are also sandy soils developed on deposit sands and independently of being more developed, its soil profile functions seems to be similar to the ones of the Arenosols, and thus also allowing a cork oak deep-root pattern characteristic in water-limited situations. The Podzols in the study area are well drained soils as the respective spodic subsurface horizon is not compact and should not occur in continuous layer but in interrupted layers (Gusmão and Madeira, 1986), allowing an increase of effective rooting depth of trees with the advantage of having a somewhat increased water storage capacity which makes the average tree response similar to that observed for Arenosols.

The Regosols in study area are developed on consolidated materials (mostly sandstones) (SROA, 1963; Cardoso, 1965). The soil parent material in these soils can be close to the surface (Endoleptic Regosols) determining a reduced soil depth, with low nutrient and moisture supplies, with negative influence on 

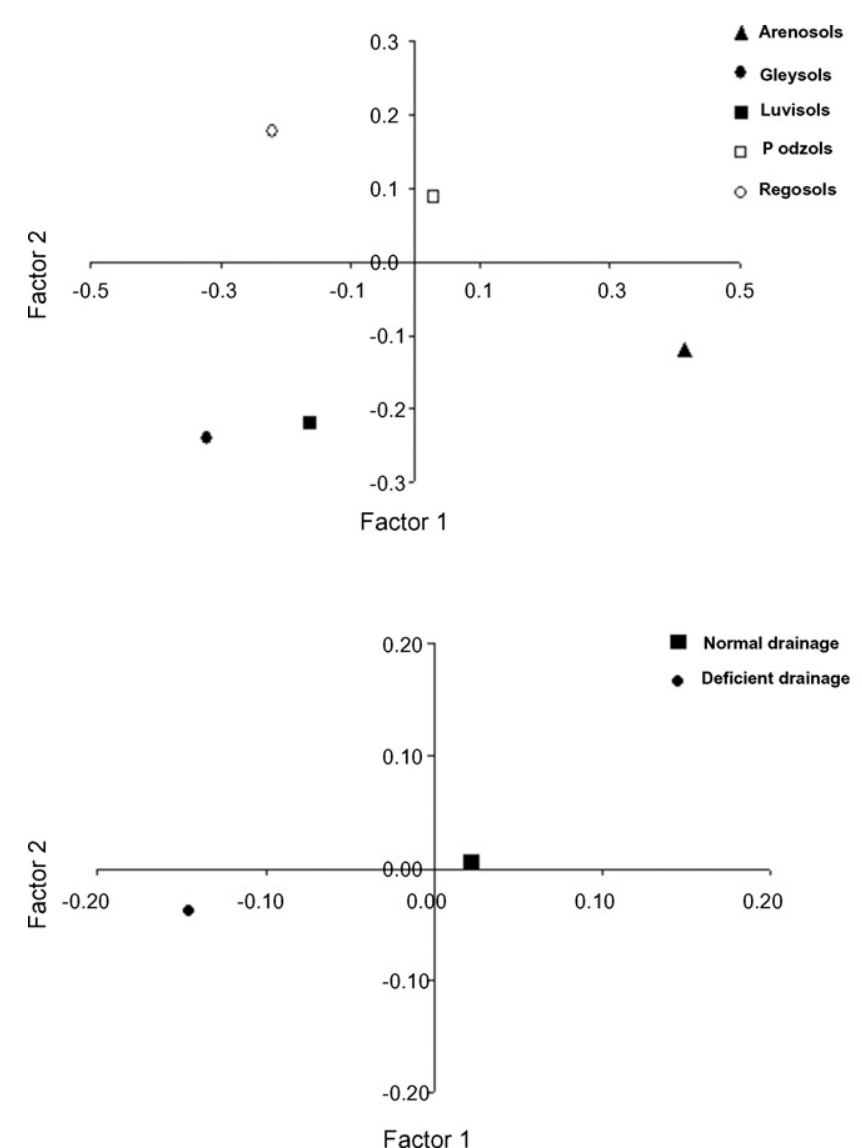
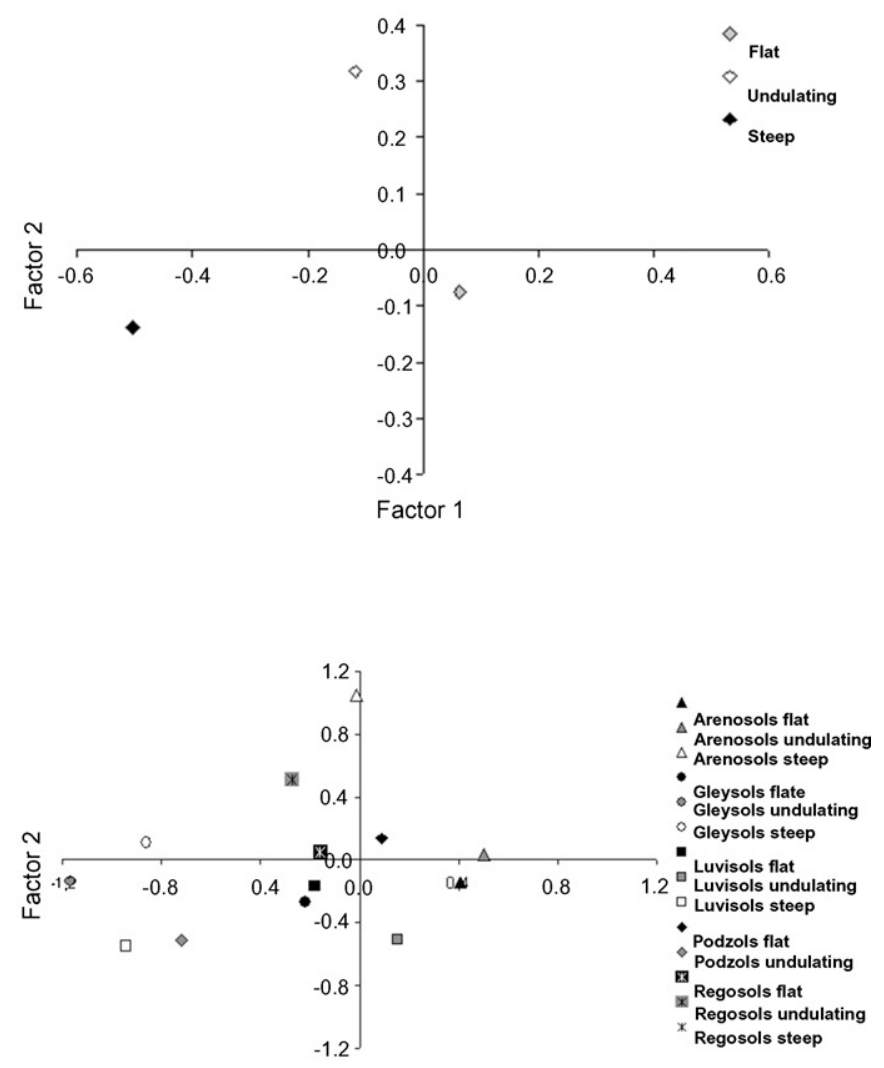

Factor 1

Fig. 4. Scatterplot of the mean of the 888 plots for the first two principal components, Factor 1 and Factor 2, in relation to: (a) RSG; (b) slope and (c) drainage and (d) RSG $\times$ slope.

tree growth (Fisher and Binkley, 2000), especially in steep slopes areas. In fact, the results obtained for cork oak parameters showed that Regosols have somewhat disadvantageous characteristics that limited to the cork oak growth, e.g., trees in Regosols were smaller, with a correspondent lower cork production, when compared to those in Arenosols and Podzols. The depth to compacted parent material and the low volume of soil available especially in the Endoleptic Regosols (depth between 0.5 and $1 \mathrm{~m}$ up to the consolidated parent material), are probably the main decisive factors which negatively influence the tree deep-rooting development pattern and the cork oak growth, by inhibiting the access to below ground water resources during summer drought (Moreno et al., 2005; David et al., 2007).

Luvisols in the study area are mostly developed in flat areas on sandstones and clay beds, showing a subsurface compacted horizon (argic) with high clay content (Cardoso, 1965). The results for cork oak parameters showed that in these soils the tree growth was low and tree size, density and cork yield presented significant lower values in relation to Arenosols and Podzols, and also to Regosols. The flat landscape and the compactness of the subsurface horizon could result in pregleyic conditions, decreasing the water drainage and cause temporary flood, inhibiting soil aeration and root development. We may emphasize that the compacted subsurface horizon also affects the cork oak deep-root development and thus negatively influence the tree growth limiting the access to below-ground resources (Fisher and Binkley, 2000; Moreno et al., 2005).

The Gleysols (Luvic) are also developed in flat areas on sandstones and clay beds. They differ from Stagnic Luvisols by the intensity and period of water saturation, and therefore, in the respective areas serious restrictions for cork oak growth as tree density, size and consequently the cork production are expected, which is in agreement with the lowest values for cork oak parameters. This is in line with the observations that cork oak cannot tolerate excessive soil water saturation or shallow water table (Natividade, 1950; Diniz, 1995), inhibiting the cork oak root functioning by poor soil aeration and by predisposing extensive colonization by pathogenic organisms (Costello et al., 1990).

Physiography is an abiotic factor that, similarly to soil, exerts strong influence on forest development and productivity (Fisher and Binkley, 2000). In accordance to this, the results of the present study indicate that slope influences cork oak growth. In the study area, slope is negatively related to soil depth (Cardoso, 1965) and in shallow soils, with low nutrient and moisture supplies, the tree growth is lower, as reported for forest systems (Fisher and Binkley, 2000). In soils which show to be more suitable for cork oak growth, like Arenosols and Podzols, the steep slopes showed a small decrease of cork production, density and tree size. In soils where limiting conditions to cork oak growth are more accentuated, like 
Regosols, the slope severely affects the cork oak growth, as the effective rooting depth in these soils is already a sensitive factor to cork oak growth and steep slopes enhanced the negative soil conditions to cork oak growth.

In the study area, the Gleysols and Luvisols, mainly located in flat areas, showed a decrease of cork oak parameters with slope. However, in Luvisols and Regosols the highest tree density, tree size and cork productivity were observed in gentle undulating slopes as in flat areas were stressed the deficient drainage soil conditions, due to landscape position, and long excessive soil water saturation periods. The drainage, in the study area, seems to be an inferred soil property, indicated primarily by soil group (e.g., texture, effective soil depth) and secondly by slope (landscape morphology).

Based on the overall influence of soil, slope and drainage, in the study area again three distinct groups were identified: (i) Arenosols (AR) and Podzols (PZ); (ii) Regosols (RG) and (iii) Luvisols (LV) and Gleysols (GL). These factors should be analyzed together for the evaluation of the "site quality" for the cork oak productivity. For instance, soils labeled as appropriate for cork oak montado could change significantly to unattractive for cork oak montado according to landscape features. For example, the Haplic Regosols, which can be considered as medium-high cork productive, in steep areas could significantly change their capacity for cork oak growth and become low cork productive soils with a considerable decrease of the exploited tree density.

In Mediterranean oak woodlands, under the same climatic conditions and management practices, where tree density is indicative of water availability (Joffre et al., 1999; Joffre and Rambal, 2006), the definition of homogeneous cork oak landscapes areas with similar cork productivity, density and crown canopy cover could be based on the characteristics of the geologic formations, soil group, slope and drainage. The cork oak montado sustainability could be threatened in a global warming scenario with an increasing drought period and severity, as the water availability conditions will be stressed in a near future. In the study area, on the Regosols, the most sensitive soil group in relation to water resources, it is expected that the cork oak will be more affected in its density and yield.

\section{Conclusions}

The cork oak growth and yield, under the same climatic conditions and under the same silvo-pastoral management system, appears to be influenced by soil, slope and drainage. Soil-site relationships could be established and the knowledge of the soil map units provides useful information about how differently the trees will grow.

Three soil groups were identified as homogeneous groups for cork oak tree growth: (i) Arenosols (AR) and Podzols (PZ); (ii) Regosols (RG) and (iii) Luvisols (LV) and Gleysols (GL). The former that showed higher cork oak growth parameters and higher cork yield was characterized by deep sandy layers. This soil groups could allow the access to groundwater and the increase of root depth, adaptative characteristics of the specie in drier areas. Soils with deficient drainage, subject to temporary flood, showed some restrictions to cork oak growth and lower tree density and cork productions.

In relation to landscape features, the slope seems to stress the negative factors to cork oak growth like shallow soil depth or excessive soil water saturation as steep slopes presented the lowest tree densities and the lowest cork yields in soils with deficient drainage.

This study, made for a stand level, based on different scales information origins (e.g., soil map and forest inventory plots), was a first approach to soil-site cork oak productivity stratification. The results were achieved at a Reference Soils Group level, and were conclusive and in accordance with the suggestions and the results reported by other authors. Further work is needed and a more precise approach should be carried out to have more clear relationships between ecological conditions and productive response of cork oak woodlands.

\section{Acknowledgements}

The authors acknowledge the cooperation and funding of Companhia das Lezírias, S.A. for the development of this study. The first author thanks FCT for a scholarship. The authors acknowledge the comments of two anonymous reviewers.

\section{References}

Antrop, M., 1993. The transformation of the Mediterranean landscapes: an experience of 25 years of observations. Landscape Urban Plan. 24 (1-4), 3-13.

Blanco, E., Casado, M.A., Costa, M., Escribano, R., Garcia, M., Genova, M., Gomez, A., Gómez, F., Moreno, J.C., Morla, C., Regato, P., Sainz, H., 1997. Los Bosques Ibéricos: Una interpretación geobotânica. Editorial Planeta, Barcelona, Spain.

Burger, J.A., Kelting, D.L., 1999. Using soil quality indicators to assess forest stand management. For. Ecol. Manage. 122, 155-216.

Cabral, M.T., Ferreira, M.C., Moreira, T., Carvalho, E.C., Diniz, A.C., 1992. Diagnóstico das causas da anormal mortalidade dos sobreiros a Sul do Tejo. Scientia gerundensis 18, 205-214.

Cabral, M.T., Lopes, F., Sardinha, R.M., 1993. Determinação das causas da morte do sobreiro nos concelhos de Santiago do Cacém, Grândola e Sines. Relatório Síntese. Silva Lusitana 1 (1), 7-24.

Cadima, I.S.P., Capelo, J., Gomes, A.A., 1995. Relação entre variáveis ambientais, tipos de condução dos povoamentos e a mortalidade do sobreiro nos concelhos de Sines, Grândola e Santiago do Cacém. Silva Lusitana 3 (1), 85-107.

Cañellas, I., Montero, G., 2002. The influence of cork oak pruning on the yield and growth of cork. Ann. For. Sci. 59, 753-760.

Cardoso, J.V.C., 1965. Os solos de Portugal. Sua classificação, caracterização e génese. 1-A Sul do rio Tejo. D.G.S.A. Lisboa.

Carreiras, J.M.B., Pereira, J.M.C., Pereira, J.S., 2006. Estimation of tree canopy cover in evergreen oak woodlands using remote sensing. For. Ecol. Manage. 223, 45-53.

Costa, M.A., 1990. Metodologias para o ordenamento do montado de sobro. Rel. Est. Eng. Silv. ISA, UTL, Lisboa.

Costa, A., Pereira, H., Oliveira, A.C., 2002. Influence of climate on the seasonality of radial growth of cork oak during a cork production cycle. Ann. For. Sci. 59, 429-437.

Costello, L.R., MacDonald, J.D., Jacobs, K.A., 1990. Soils aeration and tree health: correlating soil oxygen measurements with the decline of estab- 
lished oaks. In: Symposium on Oak Woodlands Hardwood Rangeland, Davis, California, USA, pp. 295-299.

Cubera, E., Montero, M.J., Moreno, G., 2004. Effect of land use on soil water dynamics in dehesas of Central-Western Spain. In: Schnabel, S., Ferreira, A. (Eds.), Sustainability of Agrosilvopastoral Systems-dehesas, montados. pp. 109-123.

David, T.S., Henriques, M.O., Kurz-Besson, C., Nunes, J., Valente, F., Vaz, M., Pereira, J.S., Siegwolf, R., Chaves, M.M., Gazarini, L.C., David, J.S., 2007. Water-use strategies in two co-occurring Mediterranean evergreen oaks: surviving the summer drought. Tree Physiol. 27, 793-803.

DGF, 2001. Inventário Florestal Nacional, Portugal Continental - 3a Revisão 1995-1998. Direcção Geral das Florestas. Lisboa.

DGRF, 2007. Resultados do Inventário Florestal Nacional 2005/06. Inventário Florestal Nacional. Direcção-Geral dos Recursos Florestais, Lisboa.

Diniz, A.C., 1994. Os solos do montado e aptidão suberícola nos concelhos de Grândola. Santiago do Cacém e Sines. Correlações com a morte prematura do sobreiro. Silva Lusitana 2 (2), 247-267.

Diniz, A.C., 1995. Solos e aptidão suberícola. O caso concreto de um montado na zona de Mora. Silva Lusitana 3 (1), 109-121.

Ferreira, F., 2000. The cork oak condition in Portugal. In: Oszako, T., Delatour, C. (Eds.), Recent Advances on Oak Heath in Europe. pp. 121-130.

Fisher, F.R., Binkley, D., 2000. Ecology and Management of Forest Soils, 3rd ed. John Wiley \& Sons, United States of America.

Gusmão, M.R., Madeira, M., 1986. Estudo dos Solos Podzolizados de Portugal Continental a partir das extracções selectivas do carbono, alumínio e ferro. Pedon 6, 55-81.

Joffre, R., Rambal, S., 2006. Tree-grass interactions in the south-western Iberian Peninsula dehesas and montados. Shecheresse 17 (1-2), 340-342.

Joffre, R., Rambal, S., Ratte, J.P., 1999. The dehesa system of southern Spain and Portugal as a natural ecosystem mimic. Agrofor. Syst. 45, 57-79.

Montero, G., 1987. Modelos para cuantificar la producción en alcornocales (Quercus suber L.) en función de la calidad de estación y de los tratamientos selvicolas. Tesis doctoral Univ. PI. Escola Técnica Superior de Ingenieros de Montes, Madrid.

Montero, G., Cañellas, I., 2003. The silviculture of cork oak woodlands in Spain. Silva Lusitana 11 (1), 1-19.

Montero, G., Torres, E., Cañellas, I., Ortega, C., 1996. Modelos de producción de corcho para alcornocales. Investigácion Agrária. Sistema y Recursos Forestales 5, 97-127.

Montero, M.J., Obrador, J.J., Cubera, E., Moreno, G., 2004. The role of dehesa land use on tree water status in Central-Western Spain. In: Schnabel, S., Ferreira, A. (Eds.), Sustainability of agrosilvopastoral systems-dehesas, montados. pp. 125-136.
Moreno, G., Obrador, J.J., 2007. Effects of trees and undestory management on soil fertility and nutritional status of holm oaks in Spanish dehesas. Nutr. Cycl. Agroecosyst. 78 (3), 253-264.

Moreno, G., Obrador, J.J., Cubera, E., Dupraz, C., 2005. Fine root distribution in dehesas of Central-Western Spain. Plant Soil 277, 153-162.

Moreno, G.M., Obrador, J.J., Garcia, E., Cubera, E., Montero, M.J., Pulido, F., Dupraz, C., 2007. Driving competitive and facilitative interactions in oak dehesas through management practices. Agrofor. Syst. 70 (1), 25-40.

Natividade, V., 1950. Subericultura. D.G.S.F.A. Lisboa.

Pereira, P.M., Fonseca, M.P., 2003. Nature vs. nurture: the making of the montado ecosystem. Conserv. Ecol. 7(3) 7. [online]URL: http://www.consecol.org/vol7/iss3/art7.

Pereira, H., Tomé, M., 2004. Non-wood products: cork oak. In: Burley, J., Evans, J., Youngquist, J.A. (Eds.), Encyclopedia of Forest Sciences. Elsevier, Oxford, pp. 613-620.

Pinto-Correia, T., 1993. Threatened landscape in Alentejo, Portugal: the Montado and other agro-silvo-pastoral systems. Landscape Urban Plan. 24, 43-48.

Pinto-Correia, T., Mascarenhas, J., 1999. Contribution to the extensification/ intensification debate: new trends in the Portuguese montado. Landscape Urban Plan. 46, 125-131.

Serrasolses, I., Llovet, J., Bautista, S., 2004. Degradación y restauración de suelos forestales mediterráneos. In: Vallejo, V.R., Alloza, J.A. (Eds.), Avances en el estudio de la gestión del monte Mediterráneo. Fundación CEAM, pp. 93-131.

Silva, J.S., Catry, F., 2006. Forest fires in cork oak (Quercus suber L.) stands in Portugal. Int. J. Environ. Stud. 63, 235-257.

Sousa, M.A., 1997. Sobreiro-Caracterização do crescimento e avaliação da produção de cortiça. Master Thesis. Instituto Superior de AgronomiaUTL, Lisboa.

SROA, 1963. Carta de Solos de Portugal na escala 1:50,000. Folhas 34 B e 35 A. Serviço de Reconhecimento Agrário. Secretaria de Estado da Agricultura, Ministério da Economia, Lisboa.

SPSS, 2004.SPSS for Windows.SPSS Inc., Chicago.

WRB, 2006. World reference base for soil resources. A framework for international classification, correlation and communication. World Soil Reports 103, second ed. FAO, Rome.

Zbyszewski, G., 1964. Carta Geológica dos arredores de Lisboa na escala 1:50,000. Nota explicativa da folha 2 (34 B) - Loures. Direcção-Geral de Minas e Serviços Geológicos. Serviços Geológicos de Portugal.

Zbyszewski, G., Ferreira, O.V., 1969. Carta Geológica de Portugal na escala 1:50,000. Nota explicativa da folha 35 A - Santo Estevão. Direcção-Geral de Minas e Serviços Geológicos. Serviços Geológicos de Portugal. 